Meta

Journal des traducteurs

Translators' Journal

\title{
The Conference Interpeter's Working Environment under the New ISO and IEC Standards
}

\section{R. Walter Jumpelt}

Volume 30, numéro 1, mars 1985

Interprétation de conférence

URI : https://id.erudit.org/iderudit/003278ar

DOI : https://doi.org/10.7202/003278ar

Aller au sommaire du numéro

Éditeur(s)

Les Presses de l'Université de Montréal

ISSN

0026-0452 (imprimé)

1492-1421 (numérique)

Découvrir la revue

Citer cet article

Jumpelt, R. W. (1985). The Conference Interpeter's Working Environment under the New ISO and IEC Standards. Meta, 30(1), 82-90.

https://doi.org/10.7202/003278ar d'utilisation que vous pouvez consulter en ligne. 


\section{THE CONFERENCE INTERPRETER'S WORKING ENVIRONMENT UNDER THE NEW ISO AND IEC STANDARDS}

R. WALTER JUMPELT

The physical and technical conditions under which conference interpreters work are monitored by the International Association of Conference Interpreters (AIIC). (1) A large part of this task takes the form of converting the essential prerequisites for this activity into technically feasible standards. The appearance of new standards on fixed and mobile booths affords us the opportunity to present our readers with a first-hand account of this subject. The author has been involved in preparing draft standards for ISO since 1972 and he has represented the interest of both conference interpreters and conference participants in ISO and IEC, first as chairman of the AIIC Technical Committee and currently as Special Adviser on Standards. The descriptor "multilingual communication" which he coined describes both his function as coordinator of interpretation services at international conferences and as consultant in the planning of conference facilities. Facilities he has helped plan include the International Congress Center (ICC) in Berlin, the Foreign Ministry and Office of the Chancellor in Bonn, the Old Opera House in Frankfurt, the Dresdner Bank in Frankfurt, the Congress Center in Hamburg (CCH), the European Patent Office in Munich, the Bank for International Settlements in Basel, and the World Bank in Washington. (ED.)

\section{PART 1 : SOME FEATURES OF SIMULTANEOUS INTERPRETING}

Each of the language professions is practiced under specific conditions and requires its own tools of the trade. It is generally known that simultaneous interpreting requires interpretation booths and sound equipment. Less well known, however, are the specifications such equipment must meet to function properly, i.e. to do what it is supposed to do. These specifications can best be derived from the special features that characterize simultaneous interpreting. (25) While many specific features can be listed, depending on one's purpose or theoretical position, one item seems essential to me for purposes of our present discussion.

The conference interpreter (17) processes information, just like all other language professionals. In simultaneous interpreting, however, unlike the other language professions, it is the speakers who set the pace, i.e. determine the time within which the information can be processed.

\section{INFORMATION VOLUME}

There are limits to the speed at which speeches and lectures can be simultaneously interpreted : interpretation is in principle possible at up to 100-120 words per minute. Such a figure may seem rather low, but it should be borne in mind that, even when deliv- 
ered at a slow pace, a speech will easily amount to some 6000 words an hour. Meetings -generally last for 6-7 hours, giving a daily total of 36000 to 42000 words. Each of the active booths processes two-thirds of this total (assuming a roughly uniform distribution where three languages are being used), i.e. approximately 28000 words. If we reckon that each interpreter handles half of this workload - this is how the work is usually divided up - we find that each conference interpreter is actively involved in processing 14 000-20 000 words ; moreover, during "breaks" while his colleague is interpreting, each interpreter passively follows what is being said. This means that the information volume processed each day is comparable to 56-90 typewritten pages. (26)

\section{INFORMATION DENSITY}

These figures should be regarded only as an order of magnitude, as in practice more is demanded of the interpreter. First, the speakers generally speak faster and, second, they compress their information, having done their thinking at their leisure before the conference, i.e. they read out their text more or less mechanically during the conference. Eight or ten such presentations per day, with manuscripts of 20 pages or more, are by no means exceptional.

The length ( $=$ information volume) and speed of presentation together produce information density. As in translation, the information has a further dimension, namely its syntactic structure.

\section{INFORMATION STRUCTURE}

Speakers at conference either speak spontaneously (off the cuff) or read from prepared texts. In the conduct of international conferences there is hardly an issue that has given rise to more misunderstandings than that of the most appropriate method of presentation. The misunderstanding begins with the assumption that a prepared text is easier to interpret than an off-the-cuff presentation. It would require a separate article to explain why this is not so. (16), (22) A further misconception is that you can put written products of any kind into the system and get a product at the other end that possesses all the characteristics of the original. But never since the profession began have conference interpreters promised that they could translate anything other than spontaneous utterances - this is the work they do best, in fact. If despite everything they also manage to provide a good simultaneous interpretation of a written presentation, they are involuntarily fostering their clients' illusions, but they are not in any way furnishing proof that mastering overly complex syntax represents an appropriate form of communication for them or their listeners. For our present purposes it is enough to remember that the interpretation of written "speeches" (22) is now regarded as something that has to be done as a matter of course and thus unfortunately belongs to the communication practices and realities of the profession. (21), (26)

Speeches and presentations at international gatherings are often marked by their syntactic complexities. Moreover, they are loaded with specific subject jargon, of the type familiar to many readers. When we consider information input speed, density, structure and complexity together, it can be seen that conference interpreters are required - nay expected - to translate often highly convoluted written sentences virtually instantaneously, in the process performing a task that would tax the capacity of many a large computer system.

Everyone will agree that work of this kind requires tremendous concentration. As such concentration can be maintained only under certain conditions, there was urgent need to investigate and monitor working conditions and lay these down in the form of clear and unambiguous specifications. In the following pages we shall endeavor to indicate what findings have been incorporated into the writing of these standards. 


\section{PART 2 : SIMULTANEOUS INTERPRETATION BOOTHS}

The booths in which conference interpreters are required to work should facilitate their work, or at the very least make it possible, by taking account of the following requirements : 1 . sound insulation ; 2 . acoustic separation; 3 . visibility; and 4. ergonomic design.

\section{SOUND INSULATION AND ACOUSTIC SEPARATION}

The primary function of booths is to shield the interpreters from distractions emanating from adjacent booths, the meeting hall, and other parts of the building. A second essential requirement is to acoustically separate the various speech acts. Each conference interpreter works into his own target language and this is channeled out using a separate transmission path. A booth is assigned to each channel by language, but this does not preclude the possibility of two languages being transmitted alternately from one booth in some cases. This spatial separation ensures the participants receive the language they select without background noise.

\section{VISIBILITY}

Interpreting includes the perception of events that are accessible only visually, such as the interplay of gestures between speaker and listeners, certain events taking place in the hall (2) that are reflected in the speaker's response, requests for the floor through the raising of hands, and visual aids (overhead projectors, graphs) that "speak for themselves" but without which the speaker cannot be understood even in his original language. One could also say that the interpreters must be among those to whom the "message" (as this term is used in discussions of communication theory) is addressed. To this end, therefore, the booth must also afford an unimpeded view of the meeting hall. Without visual contact with the participants and the proceedings, it is difficult to identify with the subject of the conference. In very large halls the sheer fact of spatial separation has an adverse effect. For all these reasons, a direct view of the meeting hall is an integral part of the Professional Code, the General Terms of Contract for freelance interpreters, and the Charter for permanent interpreters, and is of course included in the standards to be discussed later.

\section{TV MONITORS AND OTHER MEDIA}

Some conference centers had the bright idea of placing the interpreters in front of TV monitors far away from the meeting hall, perhaps even in the basement. While monitors can be useful in supplementing a direct view of the proceedings, the planners failed to realize that they cannot replace such a view. The factors arguing against relying solely and exclusively on monitor screens include alienation, detachment from the conference proceedings, stress, and eye fatigue. Nevertheless, we recognize that an enlarged view of the speakers or of numerical data can provide more relevant information than a direct view - particularly in the case of speakers who under normal conditions are visible only from the rear. A combination of direct visibility and use of a split-screen image (e.g. overall view plus close-up) holds out the promise of providing a larger amount of information.

The trend toward teleconferencing and satellite transmission compels us in any event to give thought to the effects of working from TV monitors. (3) In AICC, the Technical Committee is looking into this matter, while the AIIC Council is examining all applications for assistance in testing new forms of media and is granting waivers where the circumstances warrant. 


\section{AIR CONDITIONING}

Interpretation booths have to be completely sealed off for acoustic reasons. On the other hand, since conference interpreters belong to the biological class of air-breathing mammals, their working area needs to be air-conditioned, even in European latitudes. The supply of fresh air must be sufficient to replenish the additional oxygen used in the highly concentrated work they do, otherwise premature fatigue sets in. The air replenishment system should work as silently as possible, so that microphones do not pick up spurious noises ; the system must not create drafts, nor must it feed in any substances that will irritate the respiratory system or cause colds. Lastly, sound bridges to other areas are to be avoided. Quite a list of design criteria, but these requirements are feasible, as a number of successful units demonstrate.

\section{BOOTH SIZE}

Like cockpit crews carrying out highly responsible tasks requiring concentrated activity in a confined space, conference interpreters work elbow-to-elbow. They do not do this voluntarily, because too much physical proximity can be distracting. What is more, too small a space is hard to deal with acoustically and from the point of view of air conditioning.

Thus booth dimensions were one of the key areas where the "interests" of conference center operators/funding agencies clashed with those of conference interpreters. The disputes that arose on hundreds of occasions would fill volumes. AIIC, the professional association of conference interpreters, (1) had to struggle for years to get the message across and finally eliminate the idea that a space the size of a telephone booth was adequate.

Even today there are people who still do not understand that interpretation booths are permanent work stations, in which conference interpreters spend half of their year (and perhaps half of their life). Many operators* argue that undersized booths in their facilities are used only sporadically. While this may be true, it does not make them any bigger, let alone more acceptable.

Let me make a further comparison to show how one-sided an approach is often taken to this issue. In administrative offices, whether belonging to a government agency or to a private corporation, it is customary to establish certain minimum sizes for working areas, rising in hierarchical fashion from clerk to division chief. There we see where a project officer sits : he has a level of university training comparable to that of a conference interpreter, earns a comparable salary, and processes perhaps one-fourth of the amount of information, but is "entitled" to at least $12-15 \mathrm{~m}^{2}$ of space. Contrast this with the AIIC demand for $3,2 \mathrm{~m}^{2}$ per conference interpreter. Is this excessive? Hardly.

\section{STANDARDIZATION}

The brief history that I have sketched here may perhaps help the reader understand why a professional organization, faced with such a lack of appreciation, decided that recommendations alone were not enough. Following detailed investigations of the physiological requirements, surveys of members and an inventorization of fixed facilities, they prepared a profile of requirements, initially in the form of a draft French standard. This formed the basis for further consultation in more than twenty countries, ultimately resulting in International Standard ISO 2603. With publication of this standard in 1974, internationally uniform requirements were for the first time laid down for booths. These included their basic dimensions : width $250 \mathrm{~cm}$ x height $230 \mathrm{~cm}$ x depth $240 \mathrm{~cm}$. In the years since then these pioneering documents have proved invaluable in designing congress centers, convention halls and other meeting places. Architects, engineers and planners have welcomed the clear statements contained in the standard on 
such subjects as siting of the booths, minimum size, sound insulation, windows, interior, lighting arrangements, color scheme, ancillary areas and accesses. This list is in itself a summary of the structural aspects of the standard ; the equipment will be described in Part 3.

\section{NEW ISO STANDARD 2603-1983}

ISO standards are reviewed at five-yearly intervals. The AIIC Technical Committee took the opportunity to reexamine the document in the light of experience gained to date with the application of ISO-2603. This process led to further negotiations, requiring a further five years. The results are embodied in a revised May 1983 edition of the standard, some $30 \%$ longer than the original version. (10) This new version now also covers conferences with more than six languages, a growing requirement in international organizations. (5), (20) For conferences involving the use of seven or eight languages, as in the EC and the UN special agencies, four interpreter positions are required to cover all languages pairs, giving a minimum width per booth of 3,40 meters. The conference center operators again raised objections on this point ; a compromise was ultimately agreed on, whereby this width is prescribed for at least booths 7 through 12 .

The wording of the 1983 version was made more precise in a number of areas, e.g. with reference to soundproofing criteria and ergonomic design of work stations and control panels. A new annex for the first time provides a clear warning against operating simultaneous interpretation and public address systems at the same time. This is in fact done in many places, disregarding the fact that it is prejudicial to listeners who have to rely on what they hear through their headphones. Echoes from loudspeakers - the use of which is justified really only when a minority of the participants are being provided with simultaneous interpretation - also make interpreting more difficult, probably because they place a considerable burden on short-term memory, which plays an important role in perception and transformation of thought.

Study of the standard shows that interpretation booths are facilities intended for highly specialized tasks. They require great technical care in their design and considerable investment. Therefore even conference centers that see frequent use should carefully consider the scope of the minimum facilities to be provided. It is generally true to say that the greatly increased acoustic separation they provide is an important argument in favor of fixed booths. Built-in booths need not detract esthetically or functionally from the meeting hall.

\section{FIXED VERSUS MOBILE BOOTHS}

The decision for or against permanent booths can be dissociated from the question of whether the transmission system (see under "Simultaneous Equipment") is built in or can be leased as and when needed. Often we are dealing with multipurpose rooms, in which case it makes sense to provide permanent booths containing the basic technical equipment, plus hard-wiring or cable conduits in the hall. Leased equipment has the advantage that it can be tailored to the type of meeting to be held and can represent the state of the art. Operators are thus protected against the risk of technical obsolescence of their system and need to tie up less capital in this way. (4)

\section{ISO STANDARD 4043}

In the case of meeting places where multilingual events are the exception (e.g. in hotels, halls used for trade fairs, etc.), operators should consider whether this occasional need could be met with mobile booths. There is a separate standard for this type of equipment, namely ISO 4043-1981 : Mobile Booths and Equipment. (11) Movable booths are subdivided into mobile and semi-permanent facilities, depending on whether 
they are designed to be transported by truck or plane or are to be used only within a building. In the latter case, the same basic dimensions apply as for permanent booths. The fully mobile units are rather smaller, much to the grief of the interpreters who have to use them. At least they are comparable with permanent booths as regards width, being made up of three basic modules of $80 \mathrm{~cm}$ each. A further disadvantage lies in the absence of an efficient system for supplying fresh air. Rapid onset of fatigue has been observed in poorly ventilated areas. This problem could, however, be solved with the use of mobile air-conditioners or by connecting the booths to the building's air-conditioning system.

It is obvious that mobile booths will always represent a compromise as regards size, weight and sound absorption, i.e. that they will never fully satisfy any of the parties involved in the communication process, the owners of the meeting hall, or the company hiring out the equipment. Thus, for example, the hum of voices from the booths can be a disturbing element if rows of chairs are set up too close to the booths.

\section{PART 3 : IEC STANDARD FOR CONFERENCE SYSTEM}

The booths alone represent only one aspect of the conference interpreter's working environment. Another aspect relates to the sound equipment through which the information is received and the interpretation product is transmitted. While even the best equipment will not help much if the interpreter is no good, the converse also holds true.

\section{TRANSMISSION EQUIPMENT}

To enable acoustically provided information (the voice of the speaker or the interpreter) to be heard by participants in the manner that they prefer, i.e. either in the original or in the selected language, electroacoustical equipment in the form of multichannel transmission systems is required. These systems, generally referred to as simultaneous interpretation systems, are also described in ISO Standard 2603, but only to the extent that they form part of the conference interpreter's immediate environment. Pursuant to the division of responsibilities between ISO (International Organization for Standardization) and IEC (International Electrotechnical Commission), Sections 5-1 1 dealing with equipment and the annex to ISO 2603 are to be supplemented by one or more standards, currently being drafted as IEC Standard : Conference Systems, (8) which will deal exclusively with the entire transmission system and its components. Consultations which started in 1979 , involving leading manufacturers of multi-channel systems in Europe and Japan as well as AIIC representatives, had not yet been completed at the time of going to press. Nevertheless, we consider it useful to indicate in this survey where these discussions currently stand.

What will be the objective of this future standard ? The first is to ensure that interpreters are able to hear the voices of the speakers over the entire frequency range, i.e. $125-12500 \mathrm{~Hz}$. There is a very good reason for this : many participants speak in a language which is not their mother tongue, e.g. when their own language is not one of the conference languages. (19) The interpreter is able to operate only within a certain technical "bandwidth"; if one of the factors involved is distorted, this may be magnified in the interpretation. Thus, the system must be able to pick up accents and articulatory imperfections with as little distortion as possible and transmit these with minimum loss, so that speech intelligibility will be preserved even under marginal conditions.

It is, however, no easy task to lay down definite criteria for speech intelligibility, i.e. criteria that can be met not only in the laboratory but also in real-life situations. The science of acoustics is having a hard time developing simple measurement procedures and formulas that can be written into standards. Intelligibility is a function of such factors as absence of spurious noise, signal-to-noise ratio between adjacent channels and 
noise inherent in the system, and last but not least the acoustic properties of the hall. There are, however, valid grounds for hoping that useful criteria can be developed.

\section{FREQUENCY RESPONSE}

Overall frequency response describes the transmission characteristics of all the elements in the transmission link, including the sound transducers (microphones and headphones). Just as with hi-fi equipment, the frequency response and linear distortion are key parameters for system developers and for interpreters to a greater extent than other parties involved in the communication process, inasmuch as the simultaneous interpreter has to both listen and speak at the same time. His own voice masks (i.e. covers) what he hears through the resonance effect. Thus the conference interpreter needs more sound level or, as the audiophile says, more sound pressure than for just listening. The conference interpreter uses a volume control to adjust his own optimum range between listening level and his own speaking voice. Special features in the speakers' voices and individual hearing requirements are adjusted using treble and bass controls.

The characteristics for high-performance headphones and microphones in the future IEC standard are of particular interest to interpreters, since only proper listening conditions allow their product to be received fully by participants.

\section{CONTROL PANELS}

Equally important for interpreters is, of course, the equipment making up their work place - the selectors, controls and indicators located on a control panel. The active elements serve to switch the microphone on and off and to select the transmission path (output channel), while the passive elements select the input channel (speaker or relay). Older systems are characterized by a totally arbitrary arrangement of these controls, probably because the designers had no idea how the interpreters actually worked. More recent systems show unmistakable progress from the point of view of ergonomics, but a uniform layout is still far to seek. In different systems, signal lamps may indicate entirely opposite things. Some switching functions are electronically locked, which means that they do not release the transmission path at the very moment when the conference interpreter ought to be "delivering the goods." So there is still scope for inventors to come up with systems that will make it easier for interpreters to familiarize themselves with a new system and prevent them from inadvertently pushing the wrong button.

\section{EQUIPMENT FOR USE BY PARTICIPANTS}

In practice, there are still many types of equipment which do not allow participants to hear properly, giving rise to the typical comment "the translation was no good" - even though the cause was technical in nature (possibly the battery voltage in the receivers was too low or the transmitter was underpowered). The IEC standard accordingly lays down characteristic values for the links to the participants, and does this separately for each of the technologies in current use (wired, inductive, and infrared). By referring to the basic document series on standardized properties of and measurement procedures for sound systems components, (9) objective specifications are being introduced for high-performance conference systems and are for the first time being made internationally binding.

\section{INFRARED TECHNOLOGY}

Among the various transmission techniques available, the infrared technology developed in the Federal Republic of Germany occupies a special place : with $8 \mathrm{kHz}$ it offers a frequency response comparable with FM reception and roughly twice as large as 
that of traditional wireless systems. The modulated signal is radiated in the conference room not by an induction loop but by transmitters and the signal is received by optical sensors on the participants' receiver sets. As the infrared rays propagate only within the hall, rather like natural light, there are additional advantages as well, such as protection against acoustic interference from neighboring halls.

\section{PART 4 : LESSONS FROM THE PAST}

AIIC publishes a Directory of Conference Facilities, (7) in which the Technical Committee evaluates meeting rooms and simultaneous interpretation facilities. Most conference facilities installed after 1974 meet the requirements laid down in the relevant standards. The number of those that are wholly in accordance with ISO 2603, however, is still small.

If we seek to discover the reason for this, we find that the shortcomings can seldom be traced to a shortage of funds, but rather to ineffective use of those funds. All too often booths and their equipment are squeezed as an afterthought into structures already planned or possibly already built - resulting in ostensible compromises at the interpreters' expense.

Exemplary facilities, among which we can mention those in the German Foreign Ministry and the Bank for International Settlements, (15) are built only when the communicative functions are recognized as central and are integrated in the architectural design process from the outset. In plain English, this means that the meeting hall as a whole must be designed from the inside out together with all its service facilities - i.e. booths, transmission system, secretariat, document reproduction, data processing, corridors and entrances - so that it is able to meet the vital needs of all the people who will be working in this area day in and day out. There is also need to allow much greater access of natural light, the beneficial effects of which on the health of participants and the liveliness of debates have long been recognized. Buildings in which this factor has been needlessly neglected are legion.

\section{TECHNICAL SUPPORT}

Architects plan conference centers usually only once in their careers. While they are open to user needs, they only learn of these through discussions. Successful projects are therefore those for which technical advice was sought and accepted. Only experts can convey to architects the realities of international meetings.

This same principle applies, mutatis mutandis, to planning the facilities needed to service the varying meeting requirements of nongovernmental and intergovernmental organizations. If the best possible sound equipment is to be procured, the equipment specifications forming part of the bidding documents must not be geared to a particular make or model, and these specifications should be prepared by independent experts with wide international experience.

Conference centers are ultimately designed to serve the needs of communication. What could be more natural than to talk to communicators who spend most of their working life in conference facilities?

Builders and planners can obtain technical support and improve their projects by calling on consultants whose field of expertise is multilingual communication.

\section{CONCLUSION}

No one examining the ISO standard can imagine from the few pages it contains how many drafts it went through and how many meetings were devoted to it. Standards require a lot of time and energy before they can be released to the public. Since the first ISO standard was published, more "human" work stations have been built and more ef- 
fective conference centers constructed. The collective efforts of a decade have been worthwhile. The writer gladly takes the opportunity afforded by this interim review to thank all who have contributed to this result.

A further report will describe the contents of the IEC standard when published.

* "Operators", in this context, also covers hotels, training centers, etc. that are not considered "conference centers" as such.

\section{BIBLIOGRAPHY}

1. AIIC : Association internationale des interprètes de conférence (AIIC), 14, rue de l'Ancien Port, CH-1211 Genève.

2. BALES, R.F. : "How People Interact in Conferences", Scientific American, March 1955, pp. 3-7; Communication in Face to Face Interaction, Penguin Modern Linguistic Readings, pp. 364-373.

3. BENZ, GROB \& HAUFTNER : Gestaltung von Bildschirmarbeitsplätzen, Verlag TÜV Rheinland, $184 \mathrm{p}$.

4. BRÄHLER, Helmut : "Diskussions- und Simultan-Dolmetscheranlagen - ein Funktions- und Kostenvergleich", $M+A$ Report Kongress Revue, 8/77.

5. DALY, Albert (May 1980) : "The Growth of Conference Languages - Is there a Limit ?", AIIC Bulletin, vol. VIII, no 1 , pp. 28-40.

6. DIN 2603 (Juni 1975) : Kabinen für simultanübertragung. Deutscher Normenausschuss (DNA), Beuth Verlag Berlin and Köln.

7. Directory of Conference Facilities, Geneva, 1981, 59 p. + 1982 Supplement.

8. IEC : Draft Standard Conference Systems, Part 1 - General, Part 2 - Electrical Requirements, $23+$ $20 \mathrm{p}$.

9. IEC Publication 268 : Sound Systems Equipment, Parts 1-15.

10. ISO 2603 (1983) : Booths for Simultaneous Interpretation, General characteristics and equipment, International Organization for Standardization (ISO), Geneva, 9 p.

11. ISO 4043 (1981): Mobile Booths - General Characteristics and Equipment.

12. JAGGERS, Barry (March 1981) : "Remote Interpreting some Reflections...", AIIC Bulletin, n० 1.

13. JUMPELT, R. Walter (April 1971) : "Kongresszentren - ein Fiasko?, Der Architekt (Bund Deutscher Architekten BDA), XX Nr. 4, pp. 108-113.

14. JUMPELT, R. Walter (October 1973) : "An Environment for Interpretation - AIIC's Programme for better Booths and Equipment", AICC Bulletin.

15. JUMPELT, R. Walter (1977) : "Konzeption der tontechnischen Anlagen in der Bank für Internationalen Zahlungsausgleich (BIZ) Basel", Planen und Bauen 7.

16. JUMPELT, R. Walter (1966) : "Vorträge bei mehrsprachigen Tagungen und ihre Simultanübertragung", Kongress Revue 1.

17. KEISER, Walter : "Der Beruf des Konferenzdolmetschers", in Volker Kapp, Übersetzer und Dolmetscher 196-209 UTB (Unitaschenbuch 325).

18. KEISER, Walter (1973): "Le phénomène de la communication dans les réunions internationales plurilingues", Équivalences, no 1, pp. 3-17.

19. KOLMER, Herbert (March 1981) : "The Struggle for the Right to one's own Language", AICC Bulletin 1, p. 24.

20. KUSTERER, Hermann (1981): "Das Sprachenproblem in den Europäischen Gemeinschaften", Lebende Sprachen, Heft 2, pp. 49-51.

21. LEDERER, Marianne (1981) : la Traduction simultanée. Expérience et théorie, Paris, Minard Lettres modernes.

22. LOCHNER, Reinhard-Karl (1964) : "Von der Technik des Simultan Übertragbaren Vortragens", Mitteilungsblatt für Dolmetscher und Übersetzer, p. 8.

23. MacFARLANE, Malcolm (August 1982) : "Interpretation : Who Talks most Sense?", Conference \& Exhibitions International, pp. 14-15.

24. D’ORVILLE, Hans (1983) : "Konferenzdienste via Satellit - die Erfahrung der Vereinten Nationen anlässlich der UNISPACE '82-Konferenz", Lebenden Sprachen, Heft 2, S. pp. 49-53.

25. SELESKOVITCH, Danica (1960): "Les conditions nécessaires à une bonne prestation de l'interprète (partie II)", Associations internationales, no 1 (January), pp. 18-21.

26. SELESKOVITCH, Danica (1968) : l'Interprète dans les conférences internationales, Paris, Lettres Modernes Minard, $261 \mathrm{p}$.

27. SELESKOVITCH, Danica (1975) : Langage, langues et mémoire, Paris, Lettres modernes Minard, 272 p. 